\title{
Passive Biomonitoring Using Integrated Hepatic Oxidative Stress Biomarkers and Gonadal Histopathology in Oreochromis Niloticus From Lake Manyame, Zimbabwe
}

\author{
Sibonani Sandra Mlambo \\ Department of Biotechnology, School of Health Sciences and Technology, Chinhoyi \\ University of Technology, P. Bag 7724, Chinhoyi, Zimbabwe \\ ssibonani@gmail.com
}

Beaven Utete

Department of Wildlife Ecology and Conservation, School of Wildlife, Ecology and Conservation, Chinhoyi University of Technology, P. Bag 7724, Chinhoyi, Zimbabwe

\section{Reagan Mudziwapasi}

Department of Crop and Soil Sciences, Faculty of Agricultural Sciences, Lupane State University, P. O. Box 170, Lupane, Zimbabwe

reaganmudziwapasi@yahoo.com

Tarshian Silibaziso Ncube

Department of Biotechnology, School of Health Sciences and Technology, Chinhoyi University of Technology, P. Bag 7724, Chinhoyi, Zimbabwe tashianncube@gmail.com

\section{Blessing Nyamupingidza}

Department of Biotechnology, School of Health Sciences and Technology, Chinhoyi University of Technology, P. Bag 7724, Chinhoyi, Zimbabwe beekundai.nyamupingidza@gmail.com 


\author{
Chipo Mungenge \\ Lake Chivero Fisheries Research Institute, P.O. Box BE 40, Belvedere, Harare \\ cmungenge@gmail.com
}

Received: June 2, 2020 Accepted: October 27, 2020 Published: November 9, 2020

doi:10.5296/ast.v9i1.17118ＵRL: https://doi.org/10.5296/ast.v9i1.17118

\begin{abstract}
The aquatic environment is particularly vulnerable to the effects of contaminants as effluents from municipal and industrial wastewater continually add numerous harmful exogenous compounds. Lake Manyame is a peri-urban freshwater reservoir that is subject to municipal and industrial discharge as well as agricultural run-off. Adult Nile tilapia (Oreochromis niloticus) were sampled from L. Manyame during low-flow and high-flow seasons from selected locations. The samples were processed in the field for histology and biochemical analysis of selected biomarkers of oxidative stress. Induction of reduced glutathione (GSH), carboxylesterase (CES) and malondialdehyde (MDA) was evident at all the sites. There were no significant variations between sites except in the last low flow season and there was an upward trend between the first season and the subsequent sampling periods. Gonadal histology did not show occurrence of any intersex as a sign of endocrine disruption. The prevalence of histological lesions in the gonads was highest in the last sampling seasons, suggesting a progressive deterioration of water quality over time.
\end{abstract}

Keywords: oxidative stress, gonadal histology, water pollution, biomarkers, O. niloticus

\title{
1. Introduction
}

The aquatic environment is the ultimate sink of toxic chemicals generated by industrial, agricultural and domestic activities. Pollutants discharged into streams and rivers are transported over long distances affecting ecosystems miles from the point of discharge. In recent decades there has been growing worldwide concern over the toxic effects that urban sewage and industrial effluent have on aquatic organisms in freshwater systems. Lake Manyame is a peri-urban lake in Zimbabwe, located in a highly populated catchment and is used for drinking water supply, small-medium enterprise fisheries, irrigation, and recreation and is one of the world destinations for bass angling. Studies have shown that some of the common fish species in L. Manyame are Oreochromis niloticus, Clarius gariepinus, Cyprinus carpio, Micopterus salmoides and Tilapia rendalii, with $O$. niloticus and $C$. gariepinus being the most commonly exploited by local fisheries (Marshall, 2011).

Concerns have been raised over dwindling fish populations, rapid discoloration of the water and its implications on water quality, fish health and reproduction in the Lake. Manyame 
River which branches to Lake Manyame is fed by highly polluted tributaries such as Marimba, Mukuvisi and Nyatsime. The major sources of pollution into L. Manyame have been identified as urban run-off, sewage effluent, agricultural run-off, which contains fertilizers, pesticides, and salts from farmland, together with eroded soils (Moyo and Mtetwa, 2002).

Biomarkers have been used extensively to provide the connection between external levels of contaminant exposure, internal levels of tissue contamination, and early adverse effects in aquatic organisms. Biomarkers of oxidative stress such as malondialdehyde (MDA), glutathione (GSH), catalase (CAT), superoxide dismutase (SOD) and peroxidase (GPx), are first class endpoints which give an indication of cellular response to pollutants at biochemical level. There is a wide range of biomarkers to assess nearly every type of chemical pollution occurring in the environment. Since induction of antioxidants represents a cellular defense mechanism to counteract toxicity of (Reactive Oxygen Species), they have been extensively used in several field studies to assess the extent of pollution in rivers, lakes and coastal waters (Goksoyr, 1995).

Both enzymatic and non-enzymatic biomarkers of oxidative stress have been shown to be sensitive indicators of aquatic pollution as they are essential to maintain the redox status of fish (Farombi et al; 2007). Cholinesterase isozymes and carboxylesterase have been shown to be suitable biomarkers of insecticide exposure (Küster, 2005, Nigam et al., 2014). As a biomarker of environmental exposure to pesticides, carboxylesterases (CES) have higher affinity than AChE for some organophosphates and carbamates (Wheelock et al., 2005). Carboxylesterases are a class of non-specific serine hydrolases which exhibit nearly irreversible phosphorylation in the presence of organophosphate cholinesterase inhibitors (Barron et al., 1999). The liver is the largest GSH reservoir. Reduced glutathione (GSH) is the major non-protein thiol and plays a pivotal role in cell viability, protecting cells against lipid peroxidation either alone or in conjugation with other proteins (Anjum et al., 2011), and also plays role in detoxification of xenobiotics and their metabolites (Al-Ghais, 2013). The presence of MDA products from lipid peroxidation also shows oxidative damage indicating oxidative stress (Saliu and Bawa-Allah, 2012). Induction of MDA was also observed in Heteropneustes fossilis (Bloch) exposed to sodium fluoride which induced oxidative stress (Yadav et al., 2015).

Histopathology of fish tissue is a reliable tool for monitoring and assessing the effects of environmental stressors, and it is one of the most reliable biomarkers to show lesions induced by anthropogenic stressors in the aquatic environment (Fernades et al., 2008; Faheem and Lone, 2017). As a tool for assessing endocrine disrupting effects in fish, histopathology has been applied in other studies assessing effects in the ovaries and testes of zebrafish (Van der Ven et al., 2003), in the adult fathead minnow (Leino et al., 2005) and in adult tilapia exposed to DDT (Mlambo et al., 2009). Histopathology is a valuable tool for the assessment of endocrine disrupting effects on fish, and has been applied by several authors (van der Ven et al., 2003; Leino et al., 2005; Kinnberg et al., 2003; van Dyk et al. 2007). Histopathological changes are often the result of the integration of a large number of interactive physiological processes; hence histopathology has received increasing interest as an endpoint. 


\section{Ml Macrothink}

In this study a suite of biomarkers of oxidative stress were applied to assess water quality and determine the nature of chemical pollutants in L. Manyame, using O. niloticus as a bioindicator. Gonadal histology was applied to screen for the occurrence of intersex and to determine possible endocrine disruption in the fish.

\section{Materials and Methods}

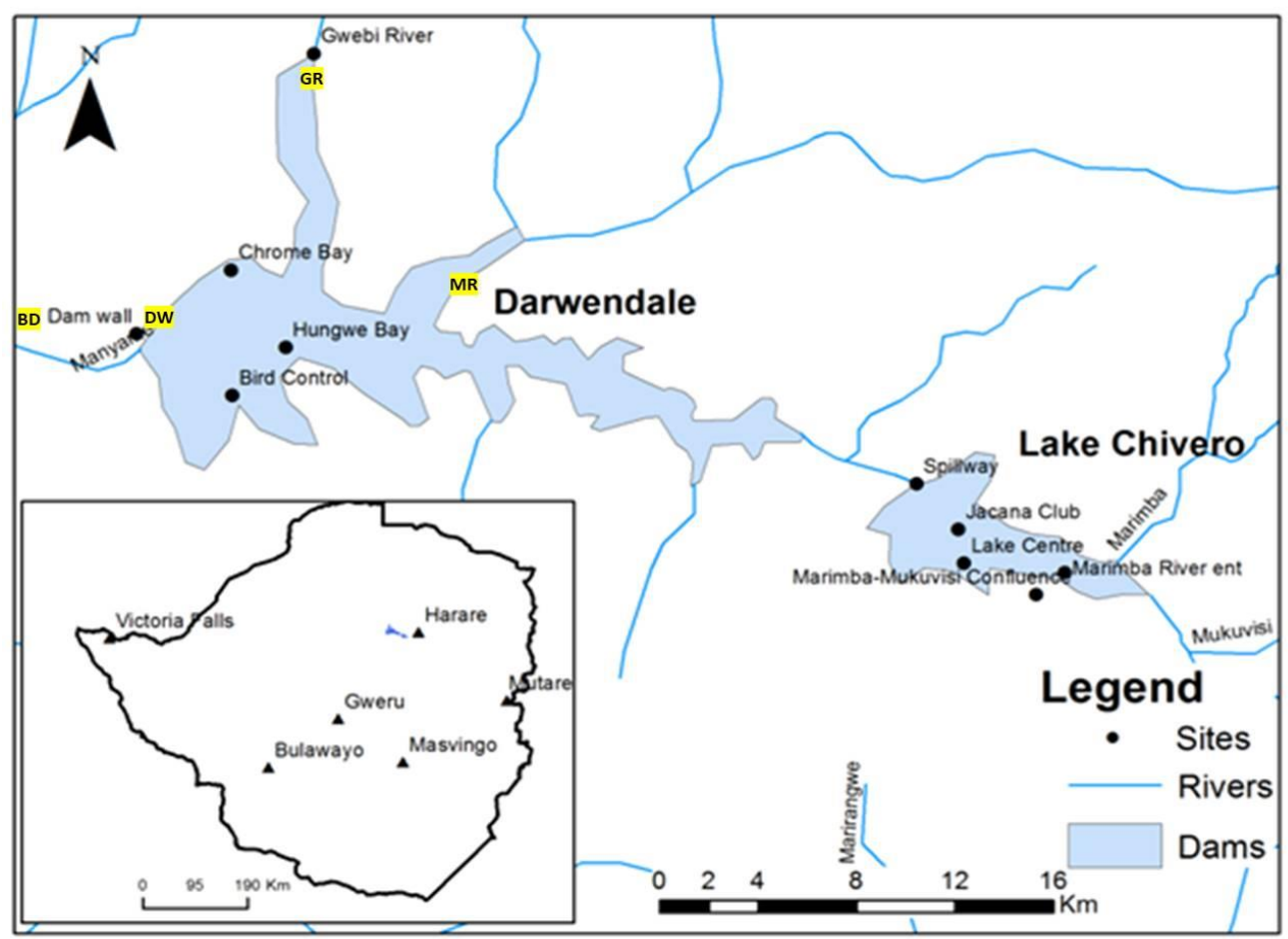

Figure 1. The location of Lake Manyame within Manyame Catchment, showing the sampling sites. The selected sampling sites were designated Site 1 Damwall (DW), Site 2 Gwebi River mouth (GR), Site 3 Muzururi confluence (MR) and Site 4 Biri Dam (BD)

\subsection{Study Site}

Lake Manyame (S1742'59.99"; E30 32' 59.99") lies downstream of Lake Chivero on the Manyame River, occupying about three-quarters of the Darwendale Recreational Park.

\subsection{Collection of Fish Samples}

Nile tilapia (O. niloticus) was sampled using gillnets from sites that are normally exploited by commercial fisheries and cooperatives. The field work was done to cover one (high-flow) and two (low-flow) seasons between February 2016 and November 2018. On-site field necropsy was performed for each sample. The sex, gutted body weight and length of the fish were recorded. The fish were killed by severing the spine just below the head (Mlambo et al., 2009). Part of the fish liver was snap-frozen in liquid nitrogen for biochemical assays. The samples were stored at $-20^{\circ} \mathrm{C}$ until the time of analysis. All the chemicals, unless stated otherwise, were purchased from Sigma Chemical Company Ltd. (Dorset, England) and were research grade biochemical suitable for cell culture. 


\subsection{Histology}

Fish gonads were excised and weighed before fixing in Bouins Fixative. Prefixed samples of ovary and testis tissue were dehydrated in an ascending series of ethanol, cleared in xylene and embedded in paraffin wax. The sections were cut at $5 \mu \mathrm{m}$, mounted on glass slides and then stained with counter stain (H\&E).

\subsection{Sample Processing for Biomarkers}

Fish liver tissue was weighed and homogenized in $0.1 \mathrm{M}$ phosphate buffer, $\mathrm{pH} 7.4$ using a hand-held homogenizer (Model D1000 Benchmark) and centrifuged at 3000rpm for 15 minutes using PowerSpin ${ }^{\mathrm{TM}} \mathrm{BX}$ centrifuge. The supernatant was transferred into microcentrifuge tubes and stored at $-20^{\circ} \mathrm{C}$, until time of analysis.

\subsection{Biomarker Analysis}

\subsubsection{MDA Assay}

Liver tissue was homogenized in 5\% trichloacetic acid (TCA) and 5\% methanolic butylated hydroxytoluene (BHT) and heated in a water bath for $30 \mathrm{~min}$ in a capped tube at $90^{\circ} \mathrm{C}$. Samples were cooled to room temperature and centrifuged at $3000 \mathrm{rpm}$ for 10 minutes. The supernatant was added to thiobarbituric acid (TBA) and heated at in a water bath at $90^{\circ} \mathrm{C}$ for $10 \mathrm{~min}$. After samples had cooled, absorbance was measured in triplicates at $533 \mathrm{~nm}$ using a FLUOstar OPTIMA microplate reader. Determination of tissue damage was carried out on the basis of production of thiobarbituric-reactive substances (TBARS). These were considered "MDA-like" products and were quantified using MDA molar extinction coefficient of $1.56 \times 105 \mathrm{M}^{-1} \mathrm{~cm}^{-1}$. The results were expressed as nmol MDA per gram of wet tissue.

\subsubsection{Glutathione Assay}

To $0.5 \mathrm{ml}$ of liver tissue homogenate $100 \mu \mathrm{l}$ of $25 \%$ TCA was added in a clean micro centrifuge tube. The samples were centrifuged at 3000x $\mathrm{x}$ for 5 minutes for the samples to precipitate. In a clean falcon tube $0.006 \mathrm{M}$ diothionitrobenzene and $0.2 \mathrm{M}$ of potassium phosphate buffer $\mathrm{pH} 8.0$ were added to the supernatant. The tubes were incubated for ten minutes at room temperature. Absorbance for all the samples was measured in triplicates at 412nm against a blank ThermoScienctificGenesys 10S UV-Vis Spectrophotometer. Glutathione content in the samples was calculated as $\mu \mathrm{m}$ GSH consumed per $\mathrm{g}$ wet tissue.

\subsubsection{Carboxylesterase Assay}

Carboxylesterase activity was determined using $p$-nitrophenyl acetate as substrate. The following reagents were added to a cuvette tube: $50 \mu \mathrm{l}$ of homogenate, $200 \mu 1$ of $0.02 \mathrm{M}$ Tris/HCl buffer, $\mathrm{pH} 7.6$ and $0.024 \mathrm{M}$ p-nitrophenyl acetate in ethanol. The production of $p$-nitrophenol was followed at $400 \mathrm{~nm}$ for 5 minutes using a Thermo Scientific Genesys 10S UV-Vis Spectrophotometer. Carboxylesterase enzyme activity was measured as $\mathrm{mM}$ p-nitrophenyl produced /mg protein /minute. 


\section{Macrothink}

\subsubsection{Protein Determination}

The protein content in the liver homogenate preparations was determined using the Bradford method, (Bradford M, 1976) using a bovine serum albumin as standard, following the manufacturer's protocol. Absorbance was read at 595nm using a FLUOstar OPTIMA microplate reader.

\subsection{Statistical Analysis}

The results were analysed using Graphpad Prism 7.0 software. One-way ANOVA was used to test significance of the results and Tukey's multiple comparisons test. All conclusions are based on at least $5 \%$ level of significance $(p<0.05)$. The mean histological scores were shown on graphs using GraphPad Prism 7.0.

\section{Results}
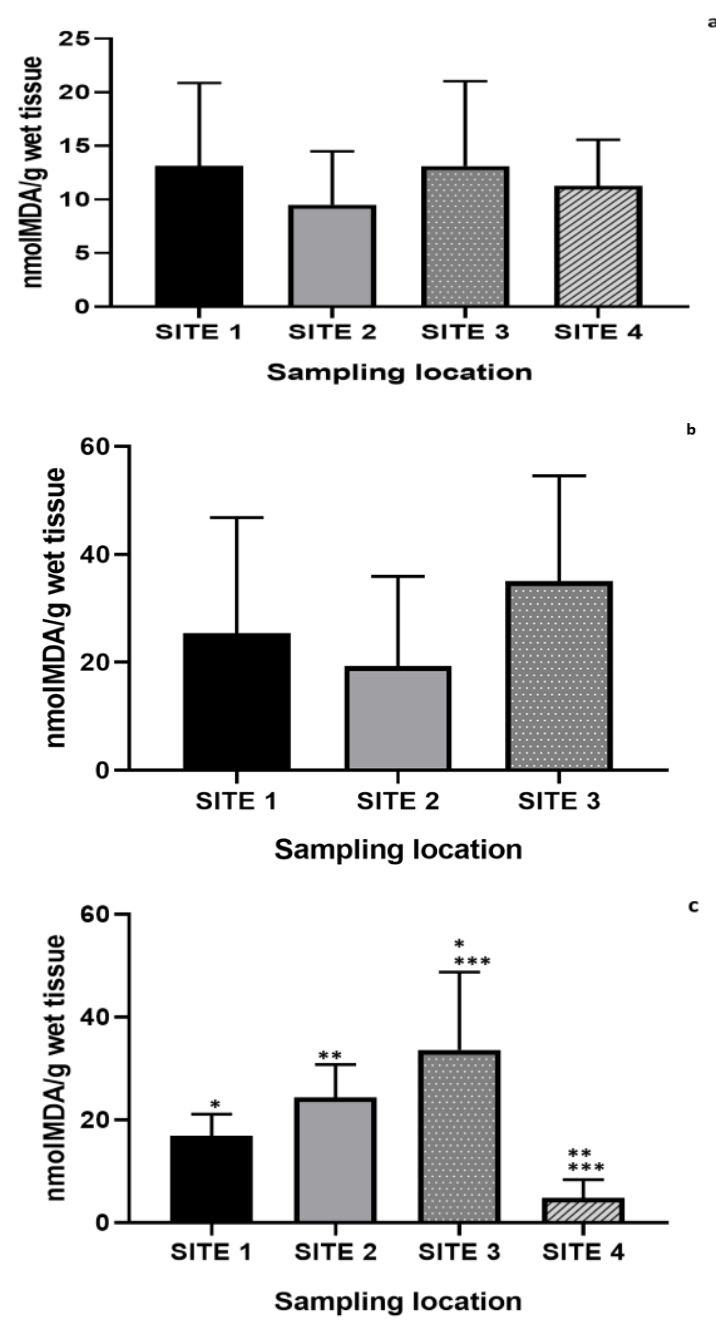

Figure 2. The mean \pm SD MDA concentration in adult $O$. niloticus from Lake Manyame and Biri Dam; a first low-flow season (LF1), b high flow season (HF), and c second low flow season (LF2)

*Statistical difference between the means was determined using One-Way ANOVA and Tukey's multiple comparisons test $(\mathrm{p}<0.05)$. 

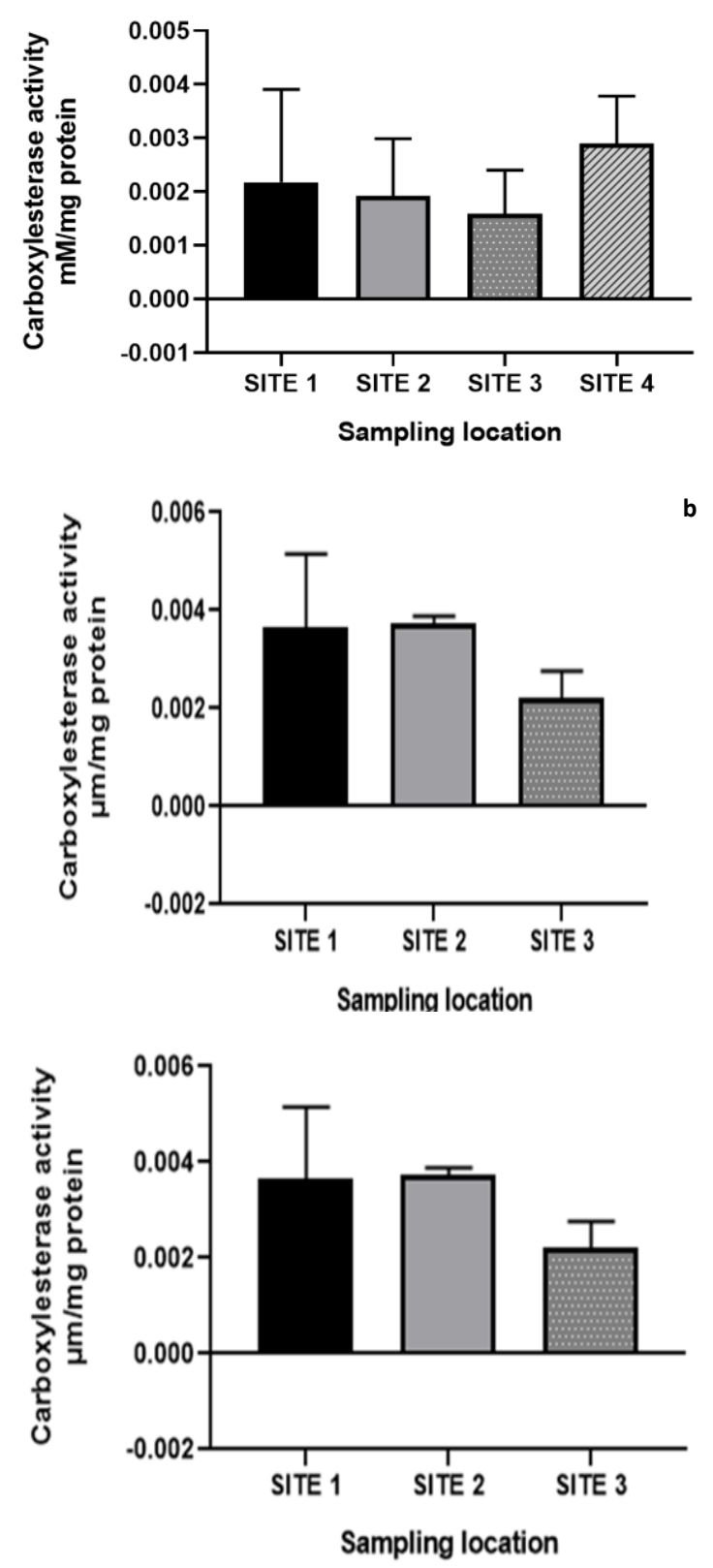

Figure 3 . The mean \pm SD carboxylesterase activity in adult $O$. niloticus from Lake Manyame and Biri Dam from a LF1, b HF, c LF2 measured as $\mathrm{mM} p$-nitrophenyl produced /mg protein /minute

*Statistical difference between the means was determined using One-Way ANOVA and Tukey's multiple comparisons test $(\mathrm{p}<0.05)$. 

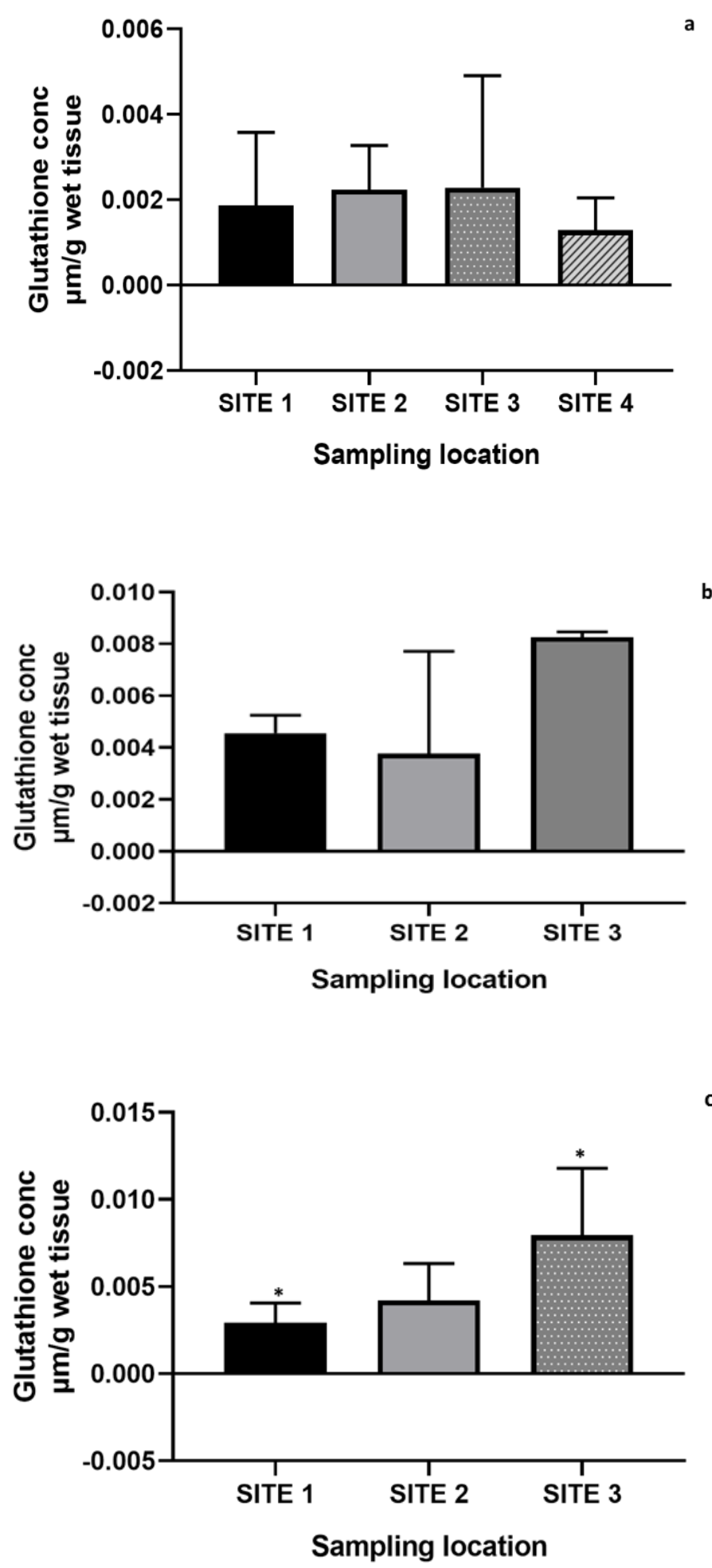

Figure 4 . The mean \pm SD glutathione activity in adult $O$. niloticus from Lake Manyame and Biri Dam from a LF1, b HF c LF2

*Statistical difference between the means was determined using One-Way ANOVA and Tukey's multiple comparisons test $(\mathrm{p}<0.05)$. 

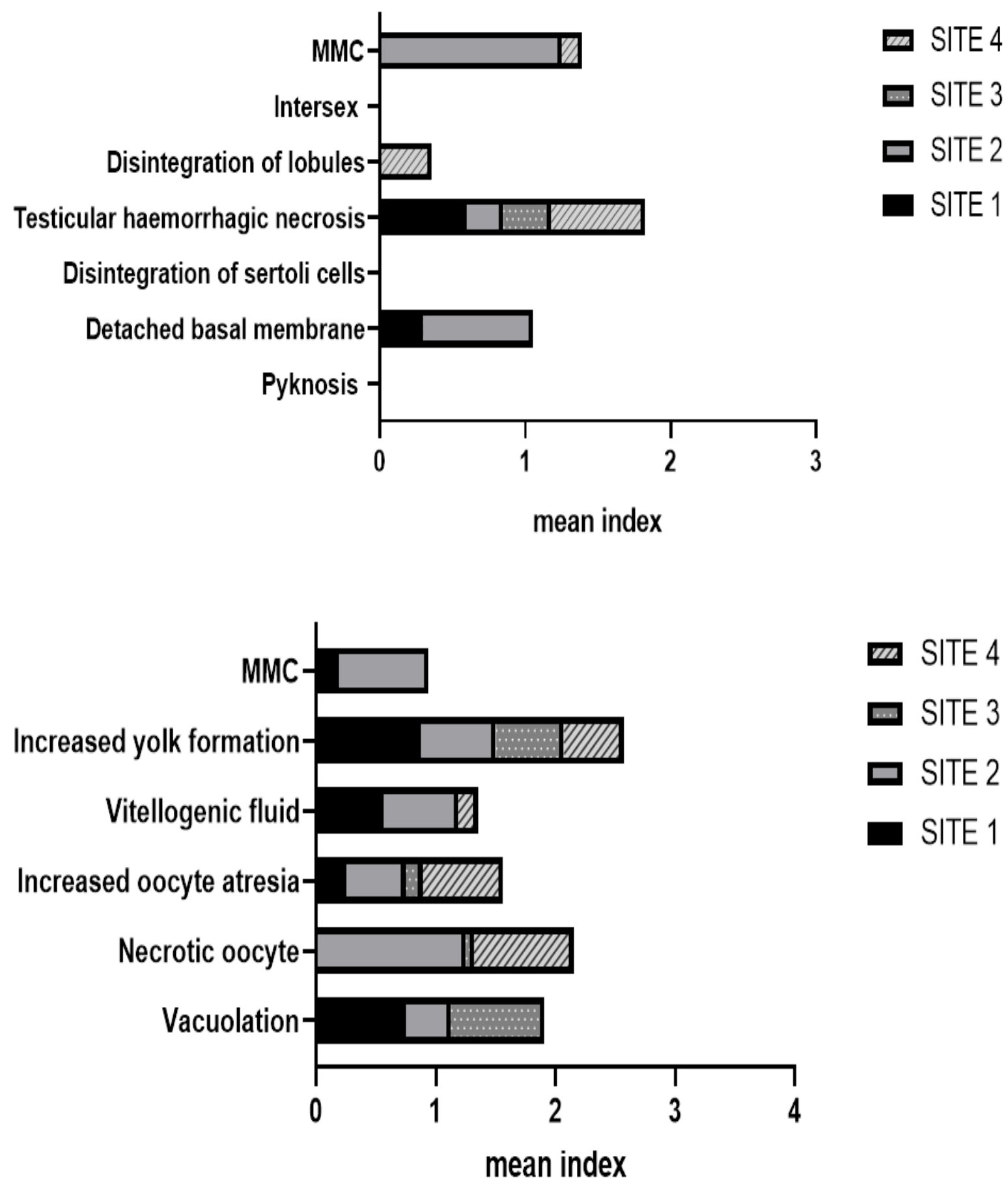

Figure 5. The mean histological score of the testes and ovaries of adult $O$. niloticus from different sites in Lake Manyame and Biri Dam in the low flow season. The highest frequencies are shown for site 1 and site 2 

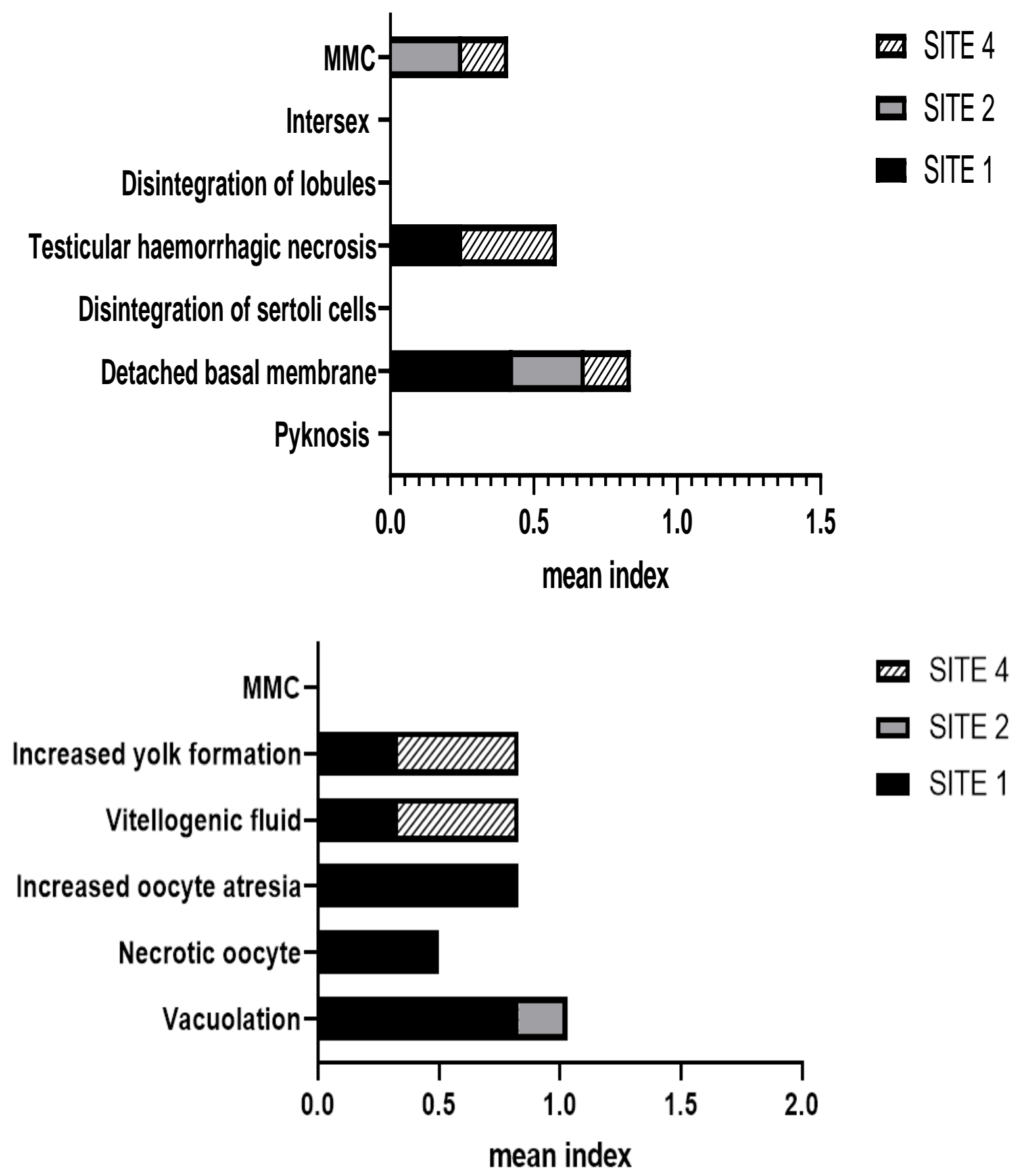

Figure 6. The mean histological score of the testes and ovaries of adult $O$. niloticus from different sites in Lake Manyame and Biri Dam in the high flow season. The highest frequencies are shown for site 1 

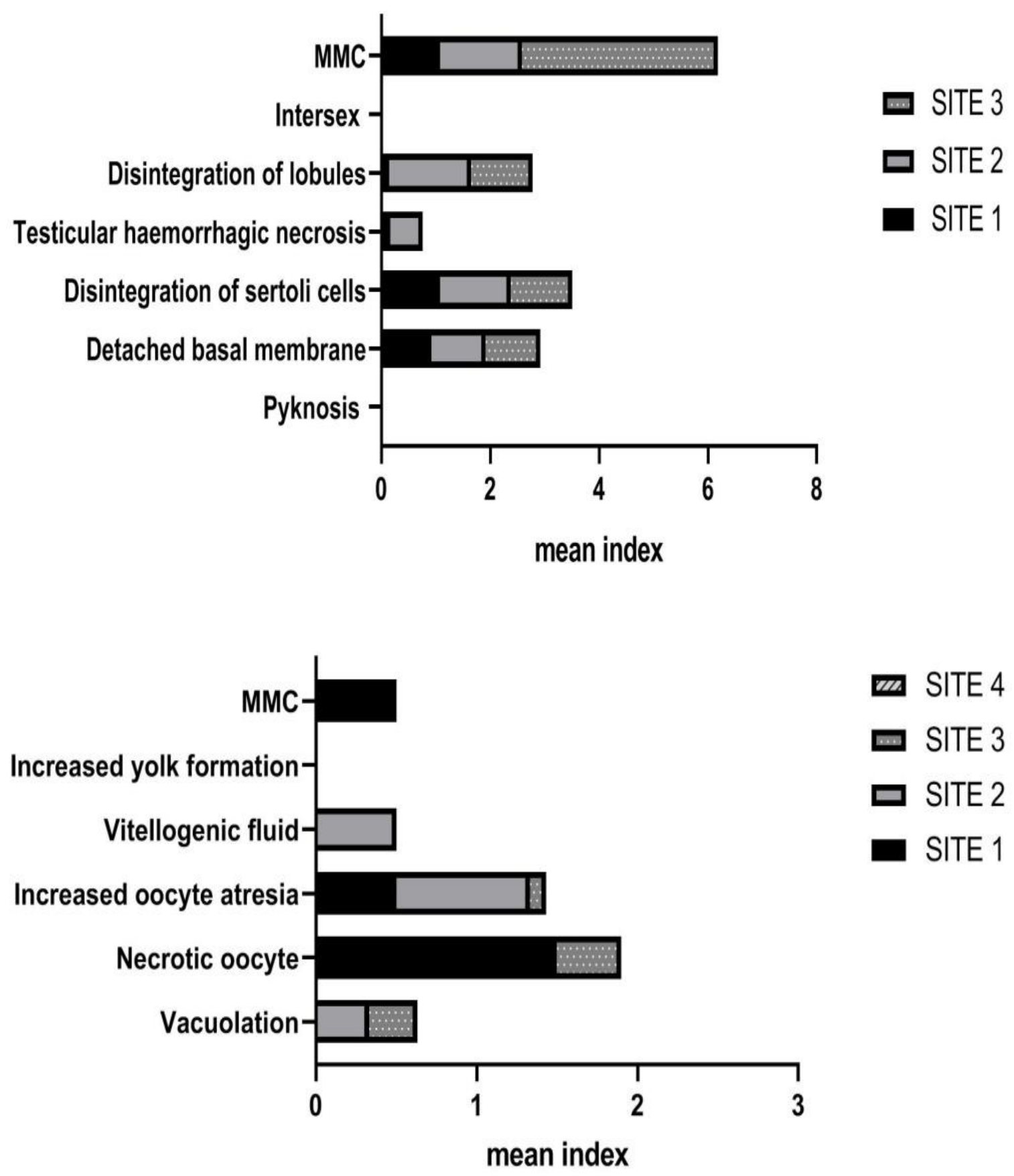

Figure 7. The mean histological score of the testes and ovaries of adult $O$. niloticus from different sites in Lake Manyame and Biri Dam in the second low-flow season 


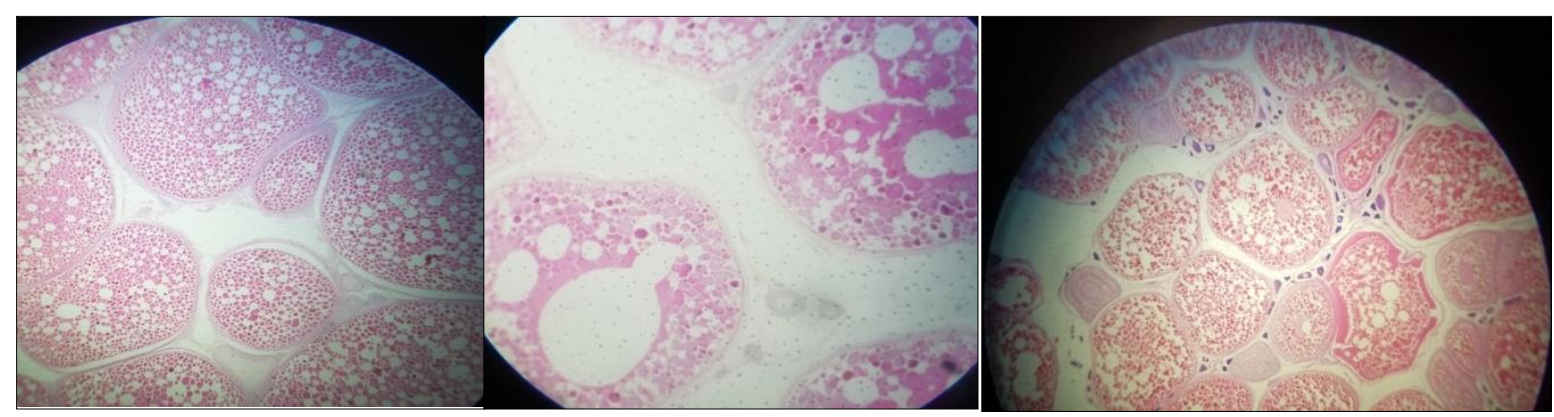

Figure 8. Histological sections showing $O$. niloticus ovaries (a) normal mature ocyte showing undisturbed vitellogenic oocytes and (b) increased vacuolation in mature vitellogenic oocyte (x10) (c) increased vitellogenic fluid (x4)
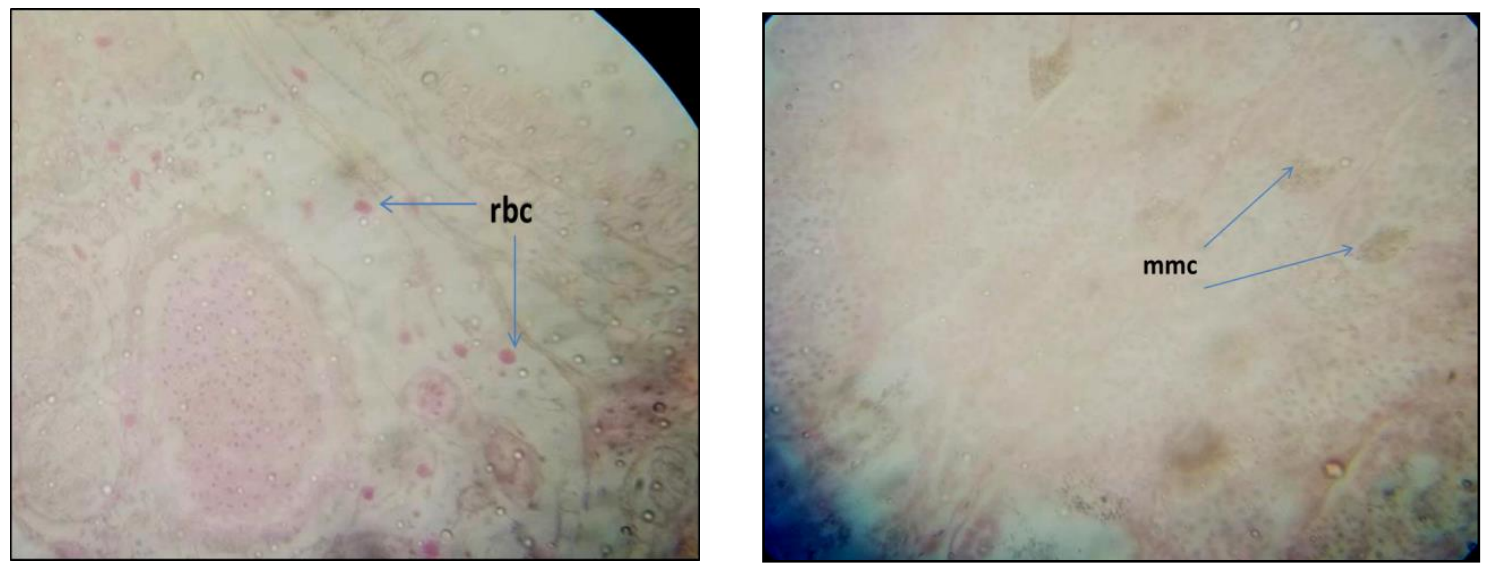

Figure 9. Histological sections of $O$. niloticus testes showing (a) Presence of red blood cells $(\mathrm{rbc})$ and (b) melanomacrophage centres (MMC)(x40)

\section{Discussion}

The effects of pollutants on ecosystems and communities originate in effects on individual organisms and ultimately, all effects of pollutants are the result of the interaction between a foreign chemical and one or several biomolecules in an individual. The ROS, which cause oxidative stress, are generated from the effect of various chemical pollutants such as heavy metal cations, polyaromatic hydrocarbons, organochlorine and phosphororganic pesticides, polychlorine biphenyls, dioxins, and other xenobiotics on aquatic organisms (Sukhovskaya et al., 2017). A survey by Masere et al. (2012) identified commercial and uncontrolled subsistence agriculture and untreated and partially treated sewage as sources of pollution emanating from tributaries in the Manyame catchment.

MDA analysis was done to measure tissue damage due to lipid peroxidation, which is a very important consequence of oxidative stress. During LF1 and high flow (HF) there was no statistically significant difference between all sites $(\mathrm{p}<0.05)$. In a study on freshwater fish (Brycon cephalus), hepatic LPO content did not vary significantly after methyl parathion treatment, indicating that the liver resisted the oxidative stress by means of antioxidant mechanisms and prevented LPO increases (Monteiro et al., 2006). Significantly elevated MDA hepatic concentrations were recorded in all the organs of $C$. gariepinus from a river compared to that of fishes from a fish farm (Farombi et al., 2007). In the present study 
significant differences were noted between sites 1 and 3, 2 and 4, and 3and 4 during the last sampling season (Fig. 2). Site 4 was by far the lowest and significantly lower than $2 \& 3$.

Carboxylesterase activity was measured as $\mathrm{mM} p$-nitrophenyl produced per $\mathrm{mg}$ protein per minute, as a biomarker for the presence of organophosphate and carbamate pesticide in the water. CES protect against the toxicity of organophosphate and organophosphorothioate insecticides in vertebrates. In all the seasons there was no statistically significant difference between the sampling sites (Fig. 4). The CES values obtained were within the same range as levels reported in hepatic microsomes from Rainbow trout (Barron et al., 1999) suggesting that these may be physiological concentrations. Fish have been shown to be an important ecological receptor for ester contaminants in the environment (Barron et al., 1999). High CES activity would indicate high concentrations of herbicides and phthalate esters and pesticide contamination in the water (Barron et al., 1999).

In LF1 and HF there were no statistically significant differences in reduced glutathione between the sampling sites. As was the case for MDA, a significant difference between sites was only observed in LF2 and for GSH it was between site 1 and 3. Induction of biomarkers of oxidative stress was evident at all the sites but at very low concentrations. Hepatic GSH was significantly higher in tilapia reared in treated sewage than those reared in clean water, demonstrating the utility of GSH as a biomarker of exposure to xenobiotics in sewage (Al-Ghais, 2013). An increase in GSH levels with concomitant elevation in the activity of GST in the organs in C. gariepinus was attributed to oxidative stress induced by the heavy metals in the environment ((Farombi et al., 2007). Exposure to sublethal concentrations of bisphenol-A (BPA) resulted in a significant decrease in reduced GSH in liver and kidney of $C$. idella. The decrease was attributed to GSH being used to scavenge the free radicals and ROS generated by BPA (Faheem and Lone, 2017).

Semi-quantitative histological analysis of male and female gonads of $O$. niloticus was done based on an adaptation of characterization and classification indexes by Bernet et al. (1999), Van Dyk et al. (2007) and Mlambo et al. (2009). The analysis focused on a set of histopathological lesions normally associated with different levels of endocrine disruption. A numerical index on the severity of different types of histopathological lesions was used (Mlambo et al., 2009). In both the low flow and high flow season histopathological lesions were high in samples from Site 1 which was the Dam Wall. Analysis of all the samples did not reveal any occurrence of intersex. Intersex is identified as mixed germ cells of both sexes in a single gonad. The other lesions which did not occur at all in all the male fish were pyknosis and disintegration of Sertoli cells. Pyknosis results from condensation of the nuclei in spermatocytes. Infiltration of red blood cells into the interstitial space, referred to as testicular haemorrhagic necrosis, was observed in some of the samples (Fig. 13a). Fig 7 shows that highest frequencies were in site 1 and site 2 , but on the scale the mean frequencies were all below 50\%. The scoring was according to how widespread an effect is in a single specimen. In Fig 8. The frequencies did not go above 22\%. The last low flow season showed the highest frequencies (Fig. 9) with a high prevalence of melanomacrophage centres in the testes (Fig. 13b) 


\section{Al Macrothink}

Aquatic Science and Technology

ISSN 2168-9148

2021, Vol. 9, No. 1

Gonadal histology did not show occurrence of any intersex, which is considered a sign of endocrine disruption. However semi-quantitative histological evaluation indicated a temporal trend of mature follicles and increased yolk formation in earlier seasons, but low maturity in the last sampling season. The male tilapia sampled had progressively lower spermatogenic activity hence low sexual maturation with subsequent seasons. The mean index values for were all below 2 for male tilapia in the first two seasons (Fig. 5 and 6) but reached a maximum value of 6 in the final season (Fig. 7) This may suggest low reproduction rates and contribute to the decreasing fish populations. In males, the last sampling season also showed higher prevalence of structural disruption of testicular lobules. The patterns of histological effects could be attributed to deterioration of water quality over time as this was consistent with the pattern observed for the biomarkers of oxidative stress.

\section{Conclusion}

In conclusion, the study confirmed the presence of chemical pollutants that induce oxidative stress in sentinel species. Effects which start from metabolic to cellular, then to the organ level, end up affecting the whole organism and ultimately the entire population and ecosystem. Though there was no significant indication of endocrine disruption, the observations point to an ecosystem threatened by poor water quality and high commercial activity. Further research should clearly establish if the fish populations are decreasing significantly in the lake, resulting in reduced fish catches. . The lake is a key economic resource for fisheries around the country because of its size and history of large supply of fish particularly $M$. salmoides and $O$. niloticus. However the lake evidently faces multiple pollution threats from the surrounding anthropogenic activities in the catchment. Future studies should also sample a wider variety of fish species and biochemical markers, factoring in the role of climate change, to further determine factors contributing to declining fish catches and poor water quality.

\section{Acknowledgements}

This work was carried out at the Department of Biotechnology, Chinhoyi University of Technology. The study was funded by the International Foundation for Science (IFS), Sweden.

\section{References}

Al-Ghais, S. M. (2013). Acetylcholinesterase, glutathione and hepatosomatic index as potential biomarkers of sewage pollution and depuration in fish. Marine Pollution Bulletin, 74, 183-186. https://doi.org/10.1016/j.marpolbul.2013.07.005

Anjum, S., Rahman, S., Kaur, M., Ahmad, F., Rashid, H., Ahmad, R. A., \& Raisuddin, S. (2011). Melatonin ameliorates bisphenol A-induced biochemical toxicity in testicular mitochondria of mouse. Food and Chemical Toxicology, 49(11), 2849-2854. https://doi.org/10.1016/j.fct.2011.07.062

Barron, M. G., Charron, K. A., Stott, W. T., \& Duvall, S. E. (1999). Tissue carboxylesterase activity of rainbow trout. Environmental Toxicology and Chemistry, 18(11), 2506-2511. 
https://doi.org/10.1002/etc.5620181117

Bernet. D., Schmidt, H., Meier, W., Burkhardt-Holm, P., \& Wahli, T. (1999). Histopathology in fish: proposal for a protocol to assess aquatic pollution. Journal of Fish Diseases, 22, 25-34. https://doi.org/10.1046/j.1365-2761.1999.00134.x

Bradford, M. (1976). A rapid method for quantification of protein utilizing the principle of

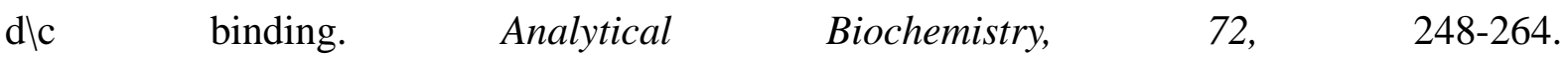
https://doi.org/10.1016/0003-2697(76)90527-3

Faheem, M. \& Lone, K. P. (2017). Oxidative stress and histopathologic biomarkers of exposure to bisphenol-A in the freshwater fish Ctenopharyngodon idella. Brazilian Journal of Pharmaceutical Sciences, e17003. https://doi.org/10.1590/s2175-97902017000317003

Farombi, E. O., Adelowo, O. A., \& Ajimoko, Y. R. (2007). Biomarkers of oxidative stress and heavy metal levels as indicators of environmental pollution in African cat fish (Clarias gariepinus) from Nigeria Ogun River. International Journal of Environmental Research and Public Health, 4(2), 158-165. https://doi.org/10.3390/ijerph2007040011

Fernandes, C., Fontainhas-Fernandes, A., Rocha, E., \& Salgado, M. A. (2008). Monitoring pollution in Esmoriz-Paramos lagoon, Portugal: Liver histological and biochemical effects in Liza saliens. Environmental Monitoring and Assessment, 145(1-3), 315-322. https://doi.org/10.1007/s10661-007-0041-4

Goksoyr, S. G. (1995). Use of cytochrome P4501A (CYP1A) in fish as a biomarker of $\begin{array}{lllll}\text { aquatic } & \text { pollution. } & \text { Aquatic } & \text { Toxicolology, } & \text { 17, }\end{array}$ https://doi.org/10.1007/978-3-642-79451-3_7

Kinnberg, K., Korsgaard, B., \& Bjerregarrd, P. (2003). Effects of octylphenol and $17 \beta$-estradiol on the gonads of guppies (Poecilia reiculata) exposed as adults via the water or as embryos via the mother. Comparative Biochemistry and Physiology. C Toxicology and Pharmacology Part C, 134, 45-55. https://doi.org/10.1016/S1532-0456(02)00206-5

Küster E. (2005). Cholin- and carboxylesterase activities in developing zebrafish embryos (Danio rerio) and their potential use for insecticide hazard assessment. Aquatic Toxicology, l( 75), 76-85. https://doi.org/10.1016/j.aquatox.2005.07.005

Leino, R. L., Jensen, K. M., \& Ankley, G. T. (2005). Gonadal histology and characteristic histopathology associated with endocrine disruption in the adult fathead minnow (Pimephales promelas). Enviromental Toxicology and Pharmacology, 19, 85-98. https://doi.org/10.1016/j.etap.2004.05.010

Marshall, B. (2011). Fishes of Zimbabwe and their biology. Smithiana Monograph 3. The South African Institute for Aquatic Biodiversity, Grahamstown.

Masere, T. P., Munodawafa, A., \& Chitata, T. (2012). Assessment of human impact on water quality along Manyame River. International Journal of Development and Sustainability, 1(3), 754-765. 
Mlambo, S. S., van Vuren, J. H. J., Barnhoorn, I. E. J., \& Bornman, M. S. (2009). Histopathological changes in the reproductive system (ovaries and testes) of Oreochromis mossambicus following exposure to DDT. Enviromental Toxicology and Pharmacology, 28, 133-139. https://doi.org/10.1016/j.etap.2009.03.011

Monteiro, D. A., de Almeida, J. A., Rantin, F. T., \& Kalinin, A. L. (2006). Oxidative stress biomarkers in the freshwater characid fish, Brycon cephalus, exposed to organophosphorus insecticide Folisuper 600 (methyl parathion). Comparative Biochemistry and Physiology Part C, 143, 141-149. https://doi.org/10.1016/j.cbpc.2006.01.004

Moyo, N., \& Mtetwa, S. (2002). Water quality management and pollution control, in Hirji, R., Johnson, P., Maro, P. and Matiza-Chiuta, T. (Eds), Defining and Mainstreaming Environmental Sustainability in Water Resources Management in Southern Africa, SARDC/World Bank, Maseru/Harare/Washington DC, pp. 135-176.

Nigam, A. K., Kumari, U., Mittal, S., \& Mittal, A. K. (2014). Characterization of carboxylesterase in skin mucus of Cirrhinus mrigala and its assessment as biomarker of organophosphate exposure. Fish Physiology and Biochemistry, 40, 635-644. https://doi.org/10.1007/s10695-013-9872-9

Nigam, A. K., Kumari, U., Mittal, S., \& Mittal, A. K. (2014). Characterization of carboxylesterase in skin mucus of Cirrhinus mrigala and its assessment as biomarker of organophosphate exposure. Fish Physiology and Biochemistry, 40, 635-644. https://doi.org/10.1007/s10695-013-9872-9

Saliu, J. K., \& Bawa-Allah, K. A. (2012). Toxicological effects of lead and zinc on the antioxidant enzyme activities of post juvenile Clarias gariepinus. Resources Environment, 2, 2126. https://doi.org/10.5923/j.re.20120201.03

Sukhovskaya, I. V., Borvinskaya, E. V., Smirnov, L. P., \& Kochneva, A. A. (2017). Role of glutathione in functioning of the system of antioxidant protection in fish (review). Inland Water Biology, 10, 97-102. https://doi.org/10.1134/S1995082917010187

Van der Ven, L. T., Wester, P. W., \& Vos, J. G. (2003). Histopathology as a tool for the evaluation of endocrine disruption in zebrafish (Danio rerio). Environmental Toxicology and Chemistry, 22(4), 908-913. https://doi.org/10.1002/etc.5620220431

Van Dyk, J. C., Pieterse, G. M., \& van Vuren, J. H. J. (2007). Histological changes in the liver of Oreochromis mossambicus (Cichlidae) after exposure to cadmium and zinc. $\begin{array}{lllll}\text { Ecotoxicology and } \quad \text { Environmental } & \text { Safety, }\end{array}$ https://doi.org/10.1016/j.ecoenv.2005.10.012

Wheelock, C. E., Eder, K. J., Werner, I., Huang, H., Jones, P. D., Brammell, B. F.,... Hammock, B. D. (2005). Individual variability in esterase activity and CYP1A levels in Chinook salmon (Oncorhynchus tshawytscha) exposed to esfenvalerate and chlorpyrifos. Aquatic Toxicolology, 74(2), 172-192. https://doi.org/10.1016/j.aquatox.2005.05.009

Yadav, S. S., Kumar, R., Khare, P., \& Tripathi, M. (2015). Oxidative stress biomarkers in the 


\section{Macrothink}

Aquatic Science and Technology ISSN 2168-9148 2021, Vol. 9, No. 1

freshwater fish, Heteropneustes fossilis (Bloch) exposed to sodium fluoride: antioxidant defense and role of ascorbic acid. Toxicology International, 22(1), 71-76. https://doi.org/10.4103/0971-6580.172261

\section{Copyrights}

Copyright for this article is retained by the author(s), with first publication rights granted to the journal.

This is an open-access article distributed under the terms and conditions of the Creative Commons Attribution license (http://creativecommons.org/licenses/by/4.0/) 